\begin{tabular}{c} 
International Journal of Engineering \& Technology, $7(4.11)(2018) 64-69$ \\
International Journal of Engineering \& Technology \\
SPC \\
Website: www.sciencepubco.com/index.php/IJET \\
Research paper \\
\hline
\end{tabular}

\title{
Adoption of Mobile Augmented Reality as a Campus Tour Application
}

\author{
Chairil Andri ${ }^{1}$, Mohammed Hazim Alkawaz ${ }^{2}$, Amira Bibo Sallow ${ }^{3}$ \\ ${ }^{1}$ School of Graduates Studies, Management and Science University, Shah Alam, Selangor, Malaysia \\ ${ }^{2}$ Faculty of Information Science and Engineering, Management and Science University, Shah Alam, Selangor, Malaysia \\ ${ }^{3}$ Department of Computer Science, College of Computers and Information Technology, Nawroz University, Kurdistan Region, Iraq \\ *Corresponding author E-mail: mohammed_hazim@msu.edu.my
}

\begin{abstract}
Campus tours are among the opportunities for colleges and universities to show their environment, facilities and achievement to the visitors or prospective students. Along with the advancement technology of mobile devices, smartphone and tablet have created new possibilities for the institutions to create mobile application which is integrated with augmented reality to engage campus visitors in new and more intuitive ways. Augmented reality can superimpose a virtual object or information into real world environments. Many universities are utilizing this technology as a mobile campus touring application to make the visitors become familiar with the campus through the self-guided devices. This paper presents a survey of mobile campus tour application based augmented reality at various universities as well as the features of each application such as information about points of interest, location search, navigation, 3D campus building, campus events, ecological environment, virtual tour, and outdoor games.
\end{abstract}

Keywords: campus tour; augmented reality; mixed reality; mobile application; mobile devices.

\section{Introduction}

A college or university normally has several buildings to accommodate the learning activities for thousands of students from various faculties and departments. The large area of campus sometimes make visitors quite easily get lost amid all the buildings [1] To solve this problem, the university parties usually held a campus tour activity to show their environment, facilities and achievement to the visitors or newcomers who first time come to the campus. Traditionally, a campus tour requires a person who knows well about campus to guide and tell the information to the visitors while walking around the campus. However, it's not always possible for visitors to remember all the information and become familiar with the campus during the one-day tour. Fortunately, the advancement of technology have brought a new way for campus tour by utilizing the augmented reality technology and let the visitors familiarize themselves with the campus via self-guided devices [1].

Augmented Reality (AR) is a field of computer research that aims to supplementing reality by mixing computer generated data and real world environments [2]. AR combine the virtual objects or the information to the real environment through the computer graphics technology which makes the virtual objects appear to originate from the existing environment [3]. In the present day, AR can be used with mobile devices, in conjunction with widespread use and emergence of smartphone and tablet from a decade earlier.

Through the prototyping and visualization of products, many universities are providing AR as a campus touring systems, and in this way allowing visitors, new students, or even the prospective students to become familiar with the campus environment. This paper presents a survey of various mobile campus tour application based augmented reality, the implementation, and the features of each application.

\section{How Augmented Reality Works}

The term of AR typically shows up in conjunction with the term Virtual Reality (VR) that can reproduce the entire world in a computer. In fact, there are some important diff erences between AR and VR systems. The main goal of a VR system is to use technology to replace reality and create an immersive environment. In contrast, the main goal of an AR system is to enhance reality with digital content in a non-immersive way [4].

A simple AR system requires at least three things, a camera, a computational unit and a display [5]. The camera captures an image of the environment, detects the marker and tracking the position of the marker, and finally media in the form of video, 3D, 2D, or text are superimposed on top of the image and displayed on the screen $[5,6]$.

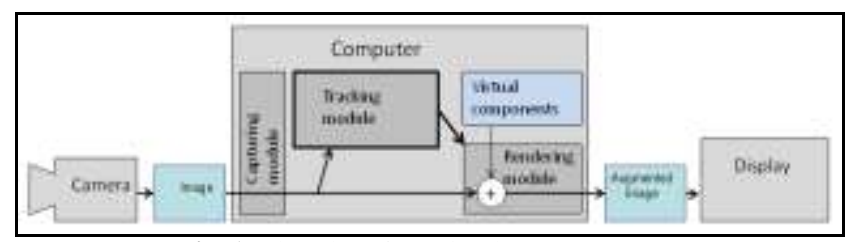

Fig. 1: Flowchart for a simple AR system [5]

In order to presents information in a correct real world context, the AR system needs to know where the user is and what the user is looking at. There are two common approaches to employing AR to present the information, that is marker-based system and marker-less system [7]. Marker-based AR systems uses specific visual 
cues such as a logo or any other simple graphic to call up the information or virtual object from a database to be overlaid to physical-world $[6,7]$.

\section{Types of AR tracking}

The tracking module is a key of the AR system, which calculates the relative pose of the camera in real time [5]. In order to register virtual content in the real world, the pose must be determined. The term "pose" means the six degrees of freedom (DOF) position, such as the 3D location and 3D orientation of an object $[4,5]$. The process to determine and updating the pose of the viewer relative to a previously known pose is called tracking [4]. Therefore, it is common to discuss different tracking techniques used for registering virtual content in the real world for the purposes of mobile AR.

\subsection{Marker Based Tracking}

The simplest way and most often used technique to achieve AR is marker-based tracking. Marker-based AR uses a camera and a visual marker to determine the center, orientation, and range of its spherical coordinate system [8]. Initially, the visual marker is a square image with a black or white border, and during the tracking phase, the system searches for this rectangle border $[9,10]$. One of the problems in marker-based technique is that the marker always has to be seen and cannot be obscured by other objects during the augmentation. This problem can be partially reduced by remembering marker position and refreshing its position accordingly with device movement [6]. Natural feature tracking and model based tracking is the further development of marker based tracking, which makes it possible to scan various type of images and 3D objects.

\subsubsection{Natural Feature Tracking}

The natural feature tracking (NFT) uses the objects or images in real world as markers by recognizing their natural cues of real elements such as edges, surface texture, or interest points $[6,11]$. Natural feature tracking can be applied to almost any image as long as the image is complex enough. An example of a natural feature tracking application is a mobile application that can recognize a cover book and identify it by comparing to similar images of cover book found on the internet [12].

\subsubsection{Model Based Tracking}

Model-based tracking makes use of a known 3D object in the scene for estimating the pose of the camera. It is works using edge detection where camera pose is estimated by matching a wireframe 3D model of an object with the real world image edge information. Unlike the common marker-based tracking, this methods does not rely on artificial patterns but on natural objects in the scene $[6,13]$.

\subsection{Marker-less Tracking}

Marker-less AR systems uses built-in components in a mobile devices such as accelerometer, compass and location data (GPS) to determine the position in the physical world which way it is pointing and on which axis the device is operating [6]. Furthermore, the fuse of data from multiple sensors in this tracking method is called the hybrid based tracking.

\subsubsection{Hybrid Based Tracking}

Most of mobile devices such as smartphone and tablet today have built-in sensors that present new opportunities for hybrid tracking
[4]. Hybrid tracking systems fuse the data from multiple sensors such as GPS (Global Positioning System), compass, gyroscope, or accelerometer to add additional degrees of freedom and calculate actual position and orientation [4, 6]. GPS allows pinpointing current location of the device to find objects in the area that are to be augmented, compass used to tell the direction of the device and check if that path has any objects to be augmented, gyroscope is used as a prediction for the feature tracker and the accelerometer is used to calculate orientation of the device using gravitation [6, 14]. Combining of technologies gives advantages for this system. The weakness of one technology can be compensated by another solution [14].

\section{Augmented Reality for Campus Tour}

The implementation of AR technology for campus tour purposes was initiated by [15] at Columbia University. This first outdoor AR system uses a head-mounted display (HMD) with GPS and orientation tracking to presents 3D graphical tour guide information to campus visitors, registered with the buildings and artifacts the visitor sees. It is required a backpack to holding a computer, various sensors, and an early tablet computer for input [16]. However, the heavy AR technologies such as HMD and computer are not easy to handle, and that AR technologies should be developed to be smaller, lighter, more portable, and fast enough to display graphics [17].

Further development of AR for campus tour purposes leads to mobile application along with the increasingly sophisticated capabilities of mobile devices. Smartphone and tablet have created new possibilities to optimize content that engages campus visitors in more innovative ways. There are many mobile AR applications developed for the campus tour purposes at various universities and some of them are written in journal articles. The following is a table of relevant past literature about the use of mobile AR as a campus tour application that taken from several databases such as IEEE, Scopus and Science Direct.

Table 1: The past literature about the use of mobile AR as campus tour application

\begin{tabular}{|c|c|c|c|}
\hline Author & Application & Tracking & Main Function \\
\hline $\begin{array}{c}{[1],} \\
2012\end{array}$ & $\begin{array}{l}\text { Augmented Reality } \\
\text { for Fu-Jen Univer- } \\
\text { sity, Taiwan }\end{array}$ & $\begin{array}{l}\text { Marker- } \\
\text { based }\end{array}$ & $\begin{array}{l}\text { Provides the information } \\
\text { about various points of } \\
\text { interest (POI) on campus }\end{array}$ \\
\hline $\begin{array}{l}{[18],} \\
2012\end{array}$ & $\begin{array}{l}\text { CAViAR for Kha- } \\
\text { lifa University, } \\
\text { UAE }\end{array}$ & $\begin{array}{l}\text { Marker- } \\
\text { based }\end{array}$ & $\begin{array}{l}\text { Indoor localization, and } \\
\text { indoor navigation }\end{array}$ \\
\hline $\begin{array}{l}{[19],} \\
2013\end{array}$ & $\begin{array}{l}\text { Mobile Campus } \\
\text { Touring System for } \\
\text { Beijing Normal } \\
\text { University, China } \\
\end{array}$ & $\begin{array}{l}\text { Marker- } \\
\text { less }\end{array}$ & $\begin{array}{c}\text { Provides the information } \\
\text { and activity of various } \\
\text { POI on campus }\end{array}$ \\
\hline $\begin{array}{l}{[20],} \\
2013\end{array}$ & $\begin{array}{l}\text { Campus Naviga- } \\
\text { tion Based on } \\
\text { Mobile AR for } \\
\text { Shenyang Univer- } \\
\text { sity of Technology, } \\
\text { China } \\
\end{array}$ & $\begin{array}{l}\text { Marker- } \\
\text { based }\end{array}$ & $\begin{array}{l}\text { Provides the exact posi- } \\
\text { tion of user and infor- } \\
\text { mation about various POI } \\
\text { on campus }\end{array}$ \\
\hline $\begin{array}{l}{[21]} \\
2014\end{array}$ & $\begin{array}{c}\text { Campus Event App } \\
\text { for Bowling Green } \\
\text { State University, } \\
\text { USA }\end{array}$ & $\begin{array}{l}\text { Marker- } \\
\text { less }\end{array}$ & $\begin{array}{l}\text { Find and show the infor- } \\
\text { mation about nearby } \\
\text { events on campus }\end{array}$ \\
\hline $\begin{array}{l}{[22]} \\
2014\end{array}$ & $\begin{array}{c}\text { Sunmap+ for Sun- } \\
\text { way University, } \\
\text { Malaysia } \\
\end{array}$ & $\begin{array}{l}\text { Marker- } \\
\text { based }\end{array}$ & $\begin{array}{c}\text { 3D campus map naviga- } \\
\text { tion }\end{array}$ \\
\hline $\begin{array}{l}{[23],} \\
2014\end{array}$ & $\begin{array}{l}\text { Lehigh Augmented } \\
\text { Campus Tour for } \\
\text { Lehigh University, } \\
\text { USA } \\
\end{array}$ & $\begin{array}{c}\text { Marker- } \\
\text { based }\end{array}$ & $\begin{array}{l}\text { Provides the information } \\
\text { about campus buildings }\end{array}$ \\
\hline $\begin{array}{l}{[24]} \\
2015\end{array}$ & $\begin{array}{l}\text { Augmented Reality } \\
\text { for ecological } \\
\text { campus } \\
\text { navigation, Chung } \\
\text { Hua University, } \\
\text { Taiwan } \\
\end{array}$ & $\begin{array}{l}\text { Marker- } \\
\text { less }\end{array}$ & $\begin{array}{l}\text { Provides the information } \\
\text { about ecological environ- } \\
\text { ment on campus }\end{array}$ \\
\hline
\end{tabular}




\begin{tabular}{|c|c|c|c|}
\hline $\begin{array}{l}{[25],} \\
2016\end{array}$ & $\begin{array}{l}\text { Augmented Reality } \\
\text { for University of } \\
\text { Quindio, Colombia } \\
\end{array}$ & $\begin{array}{c}\text { Marker- } \\
\text { based }\end{array}$ & $\begin{array}{c}\text { Provides the information } \\
\text { about various POI on } \\
\text { campus }\end{array}$ \\
\hline $\begin{array}{l}{[26],} \\
2016\end{array}$ & $\begin{array}{c}\text { AR Game for } \\
\text { Discovering } \\
\text { Landmarks of Mil. } \\
\text { Nueva Granada } \\
\text { University, Co- } \\
\text { lombia }\end{array}$ & $\begin{array}{c}\text { Marker- } \\
\text { based }\end{array}$ & $\begin{array}{l}\text { Provides the information } \\
\text { about POI on campus } \\
\text { through the mini-games }\end{array}$ \\
\hline $\begin{array}{l}\text { [27], } \\
2016\end{array}$ & $\begin{array}{l}\text { Augmented Reality } \\
\text { for Campus of the } \\
\text { Autonomous Uni- } \\
\text { versity of Nayarit, } \\
\text { Mexico }\end{array}$ & $\begin{array}{c}\text { Marker- } \\
\text { based }\end{array}$ & $\begin{array}{l}\text { Provides information on } \\
\text { the location of points of } \\
\text { interest within the UAN } \\
\text { campus }\end{array}$ \\
\hline $\begin{array}{l}{[28],} \\
2017\end{array}$ & $\begin{array}{l}\text { Augmented Reality } \\
\text { for Smart Campus } \\
\text { Urbanization, } \\
\text { MSKU, Turkey }\end{array}$ & $\begin{array}{c}\text { Marker- } \\
\text { less }\end{array}$ & $\begin{array}{l}\text { Provides the information } \\
\text { about various POI loca- } \\
\text { tion on campus }\end{array}$ \\
\hline $\begin{array}{l}\text { [29], } \\
2017\end{array}$ & $\begin{array}{l}\text { MyARCampus for } \\
\text { Patras University, } \\
\text { Greece }\end{array}$ & $\begin{array}{c}\text { Marker- } \\
\text { based }\end{array}$ & $\begin{array}{l}\text { Provides the information } \\
\text { about various POI loca- } \\
\text { tion on campus }\end{array}$ \\
\hline $\begin{array}{l}{[30],} \\
2017\end{array}$ & $\begin{array}{l}\text { iMAP-CampUS for } \\
\text { Macquarie Univer- } \\
\text { sity, Australia } \\
\end{array}$ & $\begin{array}{c}\text { Marker- } \\
\text { less }\end{array}$ & $\begin{array}{l}\text { Provides the information } \\
\text { about various POI on } \\
\text { campus } \\
\end{array}$ \\
\hline $\begin{array}{l}31], \\
2017\end{array}$ & $\begin{array}{l}\text { Semantic Web and } \\
\text { Augmented Reality } \\
\text { for University of } \\
\text { Cuenca, Ecuador }\end{array}$ & $\begin{array}{c}\text { Marker- } \\
\text { less }\end{array}$ & $\begin{array}{l}\text { Advanced search to find } \\
\text { people, events and POI } \\
\text { within campus }\end{array}$ \\
\hline
\end{tabular}

\section{Features in Mobile Augmented Reality Campus Tour}

Content and media are the key when creating meaningful campus tour application. The effective and user-centered campus tour application is not only provide users with the environmental information, but also allow users to quickly access useful features and increase environmental awareness. Based on the table of previous literature above, there are several useful features that can be applied to mobile AR campus tour application, and in this section we will discuss each of these features.

\subsection{Points of Interest Information}

The main feature of mobile AR campus tour application is to provide the information about various points of interest (POI) within the campus area. In this case, almost all of the applications in the list have this feature. In [1, 19, 23, 24, 28, 30, 31], information related to POI in campus is shown by using markerless tracking method. They use GPS to detect current location of the user and find the nearby POI to be augmented automatically. Since the location data from GPS is important, these applications will not work without internet connection. Instead, [18, 20, 25-27, 29] are using the image-markers that have been placed in various POI location on campus. If the user scans one of the markers, an information about POI in at the scanned marker will appear. Since the information has been prepared beforehand and stored in the database, these applications are possible to running without internet connection.

\subsection{Location Search}

Location search is also an important feature in mobile AR campus tour application and usually related to the navigation feature. Augmented Reality for University of Cuenca [31] is an application that implements advance search feature. This application using semantic web searching service that can process the general keywords such as people, place or event, into a specific result. Once the results are on the mobile application, the user can visualize the location of each of them through an augmented reality view.

\subsection{Navigation within Campus Area}

Navigation feature is another important point for a campus tour application to help the users find their destination, since the campus normally has a large area and consists of various buildings. Most of applications that have this feature such as $[1,18,20,21$, $23,27,29,30]$ still rely on third-party map application which means that the navigation provided is not overlaid into the existing reality. However, there are some applications that provides different navigation experience. Sunmap+ [22], provides 3D navigation indicators that can be viewed real time on the smartphone camera. AR Game for Mil. Nueva Granada University [26], provides ingame campus navigation. Another applications such as $[24,28]$ provides a radar to scan various POI at campus within 100 meters radius.

\subsection{Shows the 3D Objects that Represent Campus En- vironment}

In order to help users understand their environment better, some developers add the 3D elements to their applications and provides a new level of interaction as information is seamlessly blended into the physical reality. Sunmap+ [22], designed as a virtual guide that display information along with the 3D map of campus. When the user scans the image-marker that have been placed in specific place on campus, a virtual 3D map will appear and at the moment the position and location of the user will also detected automatically. The application then will continue to track the user's movement and navigate the users to their destination by overlaying turn-by-turn navigation indicators onto the camera live feed [22].

Another example is Augmented Reality for University of Quindio [25], which provides a 3D directional board model that can appear if the user scans an image marker located in a strategic locations of the university, and Augmented Reality for Campus of the Autonomous University of Nayarit [27] which provides 3D visualization of various wall paintings (murals) on several buildings in the campus. Other applications like $[1,18,20,23]$ also put the 3D elements in their content but did not quite represent the campus environment.
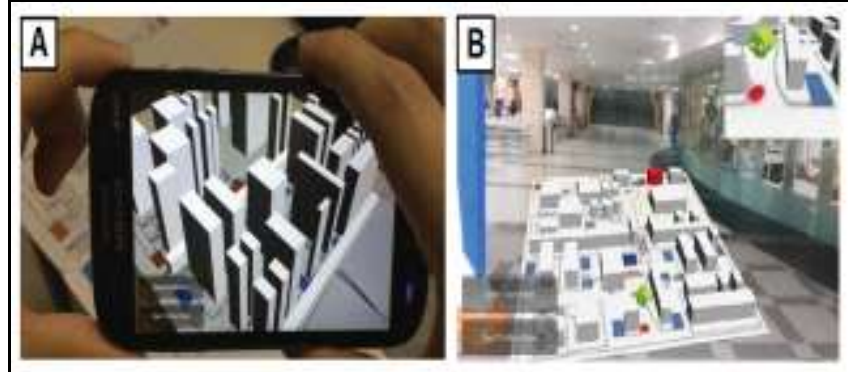

Fig. 2: The interface of Sunmap+ (A): Virtual 3D map being augmented over a physical floor plan, (B): Virtual navigator with navigation path [22]

\subsection{Shows the Events and Activities around Campus}

Information related to student events and activities can also be used as one of the features in mobile AR campus tour applications. Mobile Campus Touring System for Beijing Normal University [19], designed to shows the activity within campus area. When the application started, the GPS information will be accessed and then POI information will be loaded relative to user's location.

When the user points the smartphone camera, for example, to the library building, a virtual object which represents the library building will be appear on the screen. User could click this virtual object and get more detailed activity information of library for learning. 


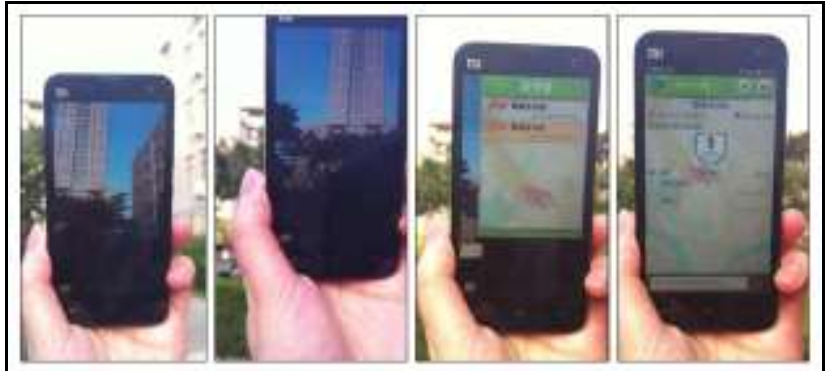

Fig. 3: AR and GPS based activity information module in Beijing Norma University [19]

Another example is Campus Event App for the Bowling Green State University [21]. If the user points the camera toward a direction, the user will be able to see virtual icon of nearby events in that direction placed over the reality. If the user selects one of the events, then the system will bring up the event detail screen. The event detail screen provides more information about the event such as the event date and time, the event location, and an event description. The screen also provides an event map and can also display the route from the user's current location to the event.
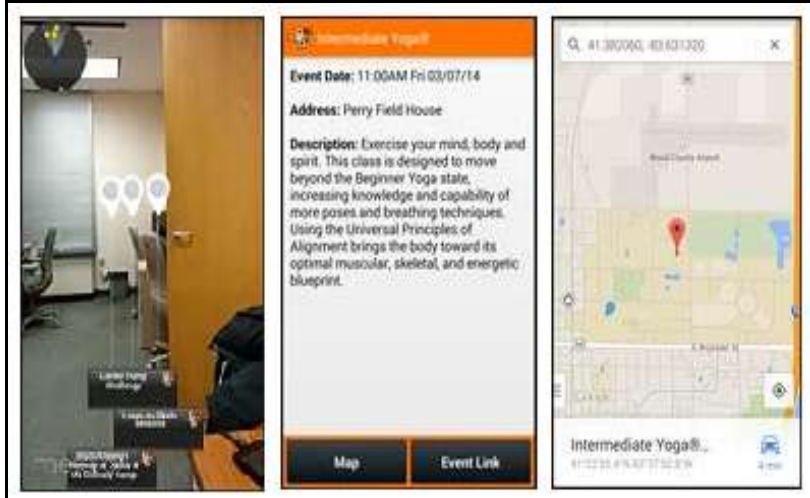

Fig. 4: AR views, event details and event map on Campus Event App [21]

\subsection{Shows the Ecological Environment in Campus}

Some universities have a variety of flora and fauna in their campus area that can attract the attention of visitors such as at Chung Hua University. By utilizing these environmental conditions, an augmented reality application are designed to provide ecological information for campus visitors [24]. Users can track the nearby POIs that inhabited by some specific fauna (birds) through their smartphone camera.

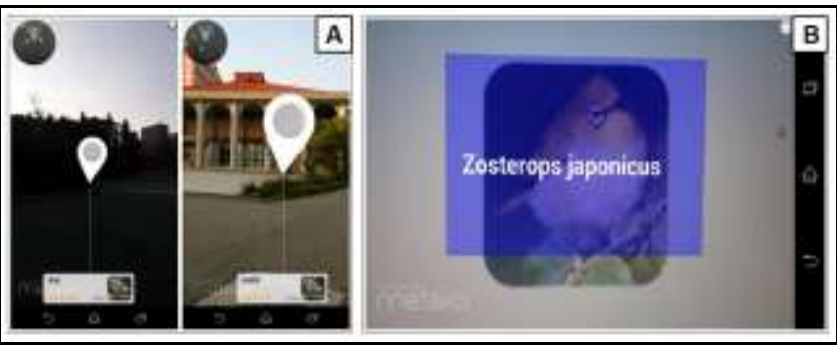

Fig. 5: The interface of AR for ecological campus (A): POI location detected on the camera, $(\mathrm{B})$ : Name of bird over the scanned image [24]

The users can also retrieve the information such as the name of bird or 3D animation video by simply scanning an image in several locations in campus.

\subsection{View inside the Campus Building}

Information related to the facilities inside the campus building is also important to help the user know better about the environment in the campus. Lehigh Augmented Campus Tour [23] have a virtual tour feature that utilizing panorama photo to provides an indoor view of the building to the user. When the application launched, user can use their smart phone camera to scan the building while visiting the campus. Once a building is matched with the database, the building information menu will appear and from this menu, the user can virtually view inside the building via 360 degree panorama photo.

\subsection{Outdoor Game}

The utilization of augmented reality technology for campus tour also has the potential to be used as a game. This can be seen in the mobile AR for Mil. Nueva Granada University [26]. This application uses various landmarks on campus as a marker to start the game and each level in the game has different markers, so the users are required to move from different places in the university. During the gameplay, each level provides information about the landmark so the users will get the basic information about it and its role at the university.

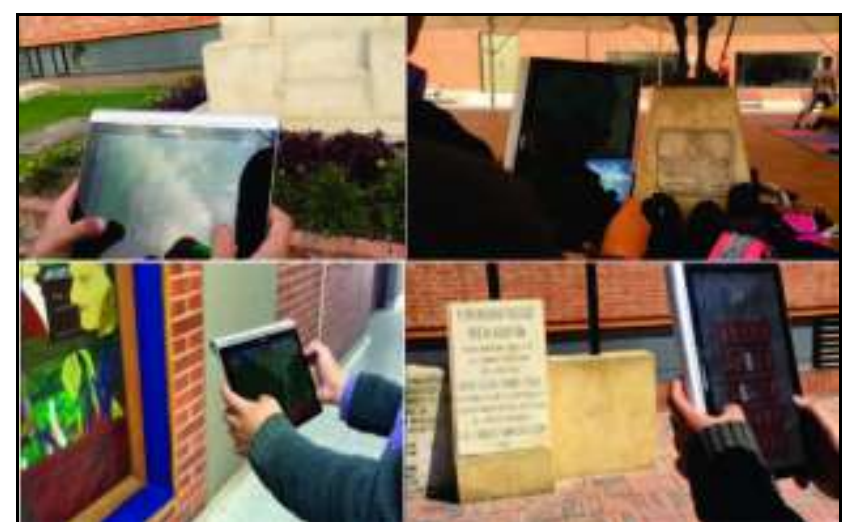

Fig. 6: AR Game execution on Mil. Nueva Granada University [26]

\section{Discussion}

The basic purpose of mobile AR campus tour application is to make university related information available to the newcomers in an easier and faster way. Besides for the newcomers, this application can also be useful for students to find the information about events and activities on campus $[19,21]$ or course time tables [29]. To improve the user experience, some interesting features are added such as 3D objects, indoor view, and games.

Search and navigation features are usually related to each other, but there are some applications such as [20-22, 24, 26-29] that have the navigation features but do not include the search features. In addition, most of the navigation features is only displayed on the map view which means the direction is not displayed directly through the smart phone camera.

Marker-based tracking method is more widely applied for mobile AR campus tour application, since it can work without using internet connection compared with marker-less tracking method that requires data from GPS to determine the user's location and the points of interest. The use of GPS also requires user to be in the campus area in order to use the application. Further development of mobile AR campus tour application should consider the virtual tour features that can be accessed anywhere to engage more users such as the prospective student from overseas who never been come to the campus. 
Table 2: Comparison based on features in mobile AR campus tour applications

\begin{tabular}{|c|c|c|c|c|c|c|c|c|c|}
\hline \multirow[b]{2}{*}{ Author } & \multicolumn{8}{|c|}{ Features } & \multirow[b]{2}{*}{ Limitation } \\
\hline & $\begin{array}{l}\text { POI } \\
\text { Info }\end{array}$ & Navigation & Search & $\begin{array}{c}\text { 3D } \\
\text { Object }\end{array}$ & $\begin{array}{c}\text { Campus } \\
\text { Event }\end{array}$ & $\begin{array}{c}\text { Indoor } \\
\text { View }\end{array}$ & $\begin{array}{l}\text { Ecological } \\
\text { Info }\end{array}$ & Game & \\
\hline$[1]$ & $\checkmark$ & $\checkmark$ & $\checkmark$ & $\checkmark$ & & & & & $\begin{array}{l}\text { The search range is restricted between } 0-5 \text { me- } \\
\text { ters, and the navigation feature still rely on } \\
\text { third-party map application. }\end{array}$ \\
\hline [18] & $\checkmark$ & $\checkmark$ & $\checkmark$ & $\checkmark$ & & & & & $\begin{array}{l}\text { The navigation feature still rely on third-party } \\
\text { map application. }\end{array}$ \\
\hline [19] & $\checkmark$ & & & & $\checkmark$ & & & & Doesn't have feature to filter the activity. \\
\hline$[20]$ & $\checkmark$ & $\checkmark$ & & $\checkmark$ & & & & & $\begin{array}{l}\text { Need to scan the image marker to get the pre- } \\
\text { cise location information. }\end{array}$ \\
\hline [21] & & $\checkmark$ & & & $\checkmark$ & & & & $\begin{array}{l}\text { Doesn't have feature to categorize the events } \\
\text { and find the distance of every event from user's } \\
\text { current location. }\end{array}$ \\
\hline$[22]$ & & $\checkmark$ & & $\checkmark$ & & & & & $\begin{array}{l}\text { 3d virtual maps only represented in cube form. } \\
\text { The application only focused on navigation } \\
\text { features. }\end{array}$ \\
\hline [23] & $\checkmark$ & $\checkmark$ & $\checkmark$ & $\checkmark$ & & $\checkmark$ & & & $\begin{array}{l}\text { No virtual objects are augmented in actual sce- } \\
\text { ne. POI information is displayed in a different } \\
\text { scene. }\end{array}$ \\
\hline$[24]$ & & $\checkmark$ & & & & & $\checkmark$ & & $\begin{array}{l}\text { The application uses only radar to navigate the } \\
\text { users. }\end{array}$ \\
\hline$[25]$ & $\checkmark$ & & & $\checkmark$ & & & & & $\begin{array}{l}\text { Virtual maps only shows the bookmarks of } \\
\text { various POI on campus and no navigation fea- } \\
\text { tures. }\end{array}$ \\
\hline [26] & $\checkmark$ & $\checkmark$ & & & & & & $\checkmark$ & $\begin{array}{l}\text { Information about POI on campus is based on } \\
\text { the game levels. Users cannot determine for } \\
\text { themselves which POI they want to visit. }\end{array}$ \\
\hline [27] & $\checkmark$ & $\checkmark$ & & $\checkmark$ & & & & & $\begin{array}{l}\text { Information about POI on campus is catego- } \\
\text { rized, but there are no filter and search features. }\end{array}$ \\
\hline [28] & $\checkmark$ & $\checkmark$ & & & & & & & $\begin{array}{l}\text { The navigation feature uses only radar, no filter } \\
\text { and search features for various POI on campus. }\end{array}$ \\
\hline [29] & $\checkmark$ & $\checkmark$ & & & & & & & $\begin{array}{l}\text { Doesn't support online database to update the } \\
\text { information. }\end{array}$ \\
\hline [30] & $\checkmark$ & $\checkmark$ & $\checkmark$ & & & & & & $\begin{array}{l}\text { All POI in reality view are displayed in the } \\
\text { same icon and do not represent different build- } \\
\text { ings. }\end{array}$ \\
\hline [31] & $\checkmark$ & & $\checkmark$ & & & & & & $\begin{array}{l}\text { Augmented reality content is only displayed } \\
\text { after the user searches something through the } \\
\text { application. }\end{array}$ \\
\hline
\end{tabular}

\section{Conclusion}

This paper presents a survey of various mobile AR campus tour applications along with the features of each application. The main purpose of mobile AR campus tour is to provide the information about campus with innovative approach and allowing the user to become familiar with the campus environment.

Information about points of interest and navigation within campus area are the common features that can be found in mobile AR campus tour application. Most of the applications requires the user to be directly on campus location since the trigger for augmented reality is in there. Furthermore, is important to make an option in the application which enable user that far away from campus to get virtual campus tour experience.

Mobile AR campus tour application is not intended to replace the traditional campus tour activities that are usually carried out by the campus parties, but it is expected to be a new media that helps these activities become more effective and memorable for the students and campus visitors.

\section{Acknowledgement}

Authors are grateful to School of Graduate Studies (SGS), Research Management Centre (RMC), and Faculty of Information Science Engineering (FISE) of Management and Science University Malaysia for their support.

\section{References}

[1] T.-L. Chou and L.-J. ChanLin, "Augmented reality smartphone environment orientation application: A case study of the Fu-Jen University mobile campus touring system," Procedia-Social and Behavioral Sciences, 46, 410-416, 2012.

[2] G. Nithin and R. S. Bhooshan, "ARTAR-Artistic Augmented Reality," Procedia Technology, 24, 1468-1474, 2016.

[3] O. Jaeyong, S. Park, and O.-S. Kwon, "Advanced navigation aids system based on augmented reality," International Journal of eNavigation and Maritime Economy, 5, 21-31, 2016.

[4] M. Billinghurst, A. Clark, and G. Lee, "A survey of augmented reality," Foundations and Trends ${ }^{\circledR}$ in Human-Computer Interaction, $8,73-272,2015$.

[5] S. Siltanen, Theory and applications of marker-based augmented reality. VTT Technical Research Centre of Finland Ltd., 2012.

[6] D. Amin and S. Govilkar, "Comparative study of augmented reality Sdk's," International Journal on Computational Science and Applications, 5, 11-26, 2015.

[7] S. Rose, D. Potter, and M. Newcombe, "Augmented Reality: A Review of available Augmented Reality packages and evaluation of their potential use in an educational context," 2010, https://ore.exeter.ac.uk/repository/bitstream/handle/10036/4049/Au gmented-Reality-final.pdf?sequence $=1$

[8] E. Coskun, Making Augmented Reality Applications with Android NDK. 2013, https://www.slideshare.net/zilk/making-augmentedreality-applications-with-android-ndk-28065038.

[9] Anymotion, What are augmented reality markers? 2018 , https://anymotion.com/en/wissensgrundlagen/augmented-realitymarker.

[10] S. Ćuković, M. Gattullo, F. Pankratz, G. Devedžić, E. Carrabba, and K. Baizid, "Marker based vs. natural feature tracking augmented reality visualization of the 3D foot phantom," 2015, 
https://s3.amazonaws.com/academia.edu.documents/41182468/558 1de5c08ae6cf036c16fcb.pdf20160115-19908cjd41t.pdf?AWSAccessKeyId=AKIAIWOWYYGZ2Y53UL3A\&E xpires $=1534053330 \&$ Signature $=2$ RKP1UcrikfvTnRRZL0TSjcGfc A\%3D\&response-content-

disposition=inline $\% 3 \mathrm{~B} \% 20$ filename\%3DMarker_Based_vs._Natur al_Feature_Trackin.pdf.

[11] M. Billinghurst, Mobile AR Lecture 2 - Technology. 2016, https://www.slideshare.net/marknb00/mobile-ar-lecture-2technology.

[12] L. Madden, Professional augmented reality browsers for smartphones: Programming for junaio, layar and wikitude. John Wiley and Sons, 2011.

[13] M. Lowney and A. S. Raj, "Model based tracking for augmented reality on mobile devices," 2016 https://pdfs.semanticscholar.org/1e28/01377f69f75d5ed362ec3bcaa 6e8673518f5.pdf.

[14] T. Sielach, Hybrid tracking for augmented reality. Master thesis, University Klagenfurt, 2009.

[15] S. Feiner, B. MacIntyre, T. Höllerer, and A. Webster, "A touring machine: Prototyping 3D mobile augmented reality systems for exploring the urban environment," Personal Technologies, 1, 208217, 1997.

[16] D. Schmalstieg and T. Hollerer, Augmented reality: Principles and practice. Addison-Wesley Professional, 2016.

[17] D. Yu, J. S. Jin, S. Luo, W. Lai, and Q. Huang, "A useful visualization technique: A literature review for augmented reality and its application, limitation and future direction," in M. Huang, Q Nguyen, \& K. Zhang (Eds.), Visual Information Communication. Massachusetts: Springer, 2009, pp. 311-337.

[18] B. A. Delail, L. Weruaga, and M. J. Zemerly, "CAViAR: Context aware visual indoor augmented reality for a university campus," Proceedings of the IEEE/WIC/ACM International Joint Conferences on Web Intelligence and Intelligent Agent Technology, 2012, pp. 286-290.

[19] L. Wong, "Mobile campus touring system based on AR and GPS: A case study of campus cultural activity," Proceedings of the $21 \mathrm{st}$ International Conference on Computers in Education, 2013, pp. 518-526.

[20] Q. Yong-Xu, L. Jia-Min, Q. Hui, Y. Bo, and J. Chang-Xu, "Campus navigation system based on mobile augmented reality," Proceedings of the 6th International Conference on Intelligent Networks and Intelligent Systems, 2013, pp. 139-142.

[21] J. T. Chao, L. Pan, and K. R. Parker, "Campus event app-new exploration for mobile augmented reality," Issues in Informing Science and Information Technology, 11, 1-11, 2014.

[22] C. Low and Y. Lee, "Sunmap+: An intelligent location-based virtual indoor navigation system using augmented reality," International Conference on Frontiers of Communications, Networks and Applications, 2014, pp. 1-6.

[23] D. Li, M.-C. Chuah, and L. Tian, "Lehigh explorer augmented campus tour (LACT)," Proceedings of the Workshop on Mobile Augmented Reality and Robotic Technology-Based Systems, 2014, pp. 15-16.

[24] K.-M. Yu, J.-C. Chiu, M.-G. Lee, and S.-S. Chi, "A mobile application for an ecological campus navigation system using Augmented Reality," Proceedings of the 8th International Conference on Ubi-Media Computing, 2015, 2015, pp. 17-22.

[25] F. D. Giraldo, E. Arango, C. D. Cruz, and C. C. Bernal, "Application of augmented reality and usability approaches for the implementation of an interactive tour applied at the University of Quindio," Proceedings of the IEEE 11th Colombian Computing Conference, 2016, pp. 1-8.

[26] J. Garay-Cortes and A. Uribe-Quevedo, "Location-based augmented reality game to engage students in discovering institutional landmarks," Proceedings of the 7th International Conference on Information, Intelligence, Systems and Applications, 2016, pp. 1-4.

[27] A. Iriarte-Solis, P. González-Villegas, R. Fuentes-Covarrubias, and G. Fuentes-Covarrubias, "Mobile Guide to Augmented Reality for Campus of the Autonomous University of Nayarit," Proceedings of the IEEE International Symposium on Mixed and Augmented Realit, 2016, pp. 1-4.

[28] U. Özcan, A. Arslan, M. İlkyaz, and E. Karaarslan, "An augmented reality application for smart campus urbanization: MSKU campus prototype," Proceedings of the 5th International Istanbul Smart Grid and Cities Congress and Fair, 2017, pp. 100-104.
[29] V. Kokorogianni, E. Papaioannou, and C. Kaklamanis, "MyARCampus: An augmented reality application for facilitating navigation in a university campus," Proceedings of the 4th International Conference on Education, Social Sciences and Humanities, 2017, pp. 49-58.

[30] H. Alqahtani and M. Kavakli, "iMAP-CampUS: Developing an intelligent mobile augmented reality program on campus as a ubiquitous system," Proceedings of the 9th International Conference on Computer and Automation Engineering, 2017, pp. 1-5.

[31] P. Contreras, D. Chimbo, A. Tello, and M. Espinoza, "Semantic Web and Augmented Reality for searching people, events and points of interest within of a University Campus," Proceedings of the 43th Latin American Computer Conference, 2017, pp. 1-10. 